\title{
A special relationship under strain: \\ Turkey and the EEC, 1963-1976
}

\author{
Elena CALANDRI
}

\section{A testing ground}

Greece and Turkey, remarked the British Foreign Office in the early 1970s, enjoyed a privileged and unique position in the external relations of the Community because their association agreements were negotiated in the early 1960s, when the Six were desperate for an international success after the failure of the European free trade area negotiations and were oblivious to GATT rules. In order to comply with article 24, the Six subscribed to the progressive establishment of a customs union intended to lead to full membership for both countries. In doing so they overlooked economic realities and created a permanent headache in EEC external relations that grew intractable as integration developed. ${ }^{1}$

As a member of the Western security community through the OECE and NATO, in 1963 Turkey became the second country to establish a political link with the EEC. This article argues that the Foreign Office analysis of the genesis of the EEC-Turkey relationship was incorrect. It confirms however that, as the EEC prepared itself for the first enlargement, doubts about the viability of the association were widespread in Community circles. Despite Turkey's extraordinary growth during the 1960s (between $11 \%$ and $12 \%$ in 1968), its economy was not in a position to deal with European competition. The economy alone, though, neither explained nor determined EEC attitudes, and during the following decade politics and the economy intersected and clashed as nationalist and Islamic movements grew in Turkey, the role of the military was enhanced, and economic development faltered. The weakening of the EEC-Turkey relationship was not only a crucial turning point that has a bearing on a currently burning issue, but was also a testing ground for the EEC's international role and self-definition.

Archival evidences show that the acceleration in the enlargement and deepening of the EEC impacted on the development of the association. Both challenged Turkey's position as a privileged partner: Britain's membership, political cooperation, institutional developments, the Mediterranean policy and a new dynamism in external relations confronted Turkey with many difficulties. Under the effect of the international recession and of domestic economic and social problems, the Nine were unwilling to extend economic privileges to the country. But they also resisted using the new political machinery. Turkey's problems were

1. United Kingdom National Archives (hereafter UKNA), FCO 30/2684, Department of Trade and Industry to Cabinet Office, The outlook for Turkey, 07.06.1972. 
seen more and more as an "external relations" question, while identity emerged as a discriminating concept.

\section{The 1963 Association Agreement}

Turkey's request to negotiate an association agreement was presented in July 1959, six weeks after the Greek application. In the doctrinally confused and politically euphoric early years of the EEC, association requests were defined as "applications to join" the Community and some went so far as to define association as "an attenuated form of adhesion". Indeed the Turkish Democrat government that made the application stressed the political goals and significance of its association request, presented as an expression of a 'European' and Western sense of belonging to an identity it was determined to fulfil in spite of the economic difficulties that would have to be overcome. Ankara explicitly referred to the need to keep pace with Greece for economic and political reasons and asked that both applications be treated in parallel. Although the first round of exploratory talks made it clear that Greece was ready to accept tighter commitments, the Six accepted the principle of parallelism.

While the Greek negotiations moved slowly towards the Athens Treaty, the Turkish ones were interrupted by a military coup in May 1960. The ensuing stalemate lasted until the end of 1961, during which time the Democrat leaders were sentenced to death, a new constitution was adopted, a five-year economic plan was drawn up under the authority of the newly established State Planning Organisation (SPO), which embodied a shift toward dirigisme and étatisme and soon became a stronghold of opposition to the EEC. ${ }^{2}$

When negotiations reopened, the Community's positive attitude had weakened. This was not a consequence of Turkish domestic events, though the return of Ismet Inönü - the comrade of Kemal Atatürk, who had kept Turkey neutral during the Second World War - evoked nationalism and mean self-interest. The new caution in EEC circles was more the result of the experience of the Greek negotiations, of the cascade of requests from Mediterranean and European countries, and of the general atmosphere in the EEC. The Greek negotiations had opened a Pandora's box of political, institutional, and economic problems; the Athens Treaty was regarded in the EEC capitals as having been too generous in the economic and institutional privileges it sanctioned, and the Six had hastened to rule out that it might be taken as a precedent. The constant pressure exerted by the Mediterranean potential candidates (Spain, Israel, Tunisia, Morocco) was a further source of alarm, especially for Italy, which, fearing the competition of their cheaper agricultural products, refused the case-by-case approach and pressed for a restrictive association doctrine. The negotiations for Britain's adhesion had

2. F. AHMAD, The Making of Modern Turkey, Routledge, London, 1993, p.130. 
prompted applications from neutral OECD countries and were expected to alter the whole framework of external relations. The Six also feared that America's dislike of preferential agreements might lead to US opposition to an EEC-Turkey treaty in GATT. Indeed, Washington regretted having voiced, albeit reluctantly, its support for Greece's association, and evaded Turkey's request for it to put pressure on the EEC to adopt a more forthcoming attitude. The US maintained that the Greek model was the bottom line compatible with its interpretation of GATT rules, but tried to avoid making any clear statements on the matter. Lastly mistrust between the Commission and member states resulted in watchful control on Commission initiatives.

Under these unfavourable auspices, the Six and the Commission debated for months about the negotiation mandate. The Dutch, and less openly the French and the Italians, argued that the only thing Turkey really needed, a constant flow of financial aid, should not be channelled through an association agreement. The majority acknowledged the political need to give Turkey association, to maintain a balance with Greece, and to counter neutralist temptations. But France and Italy resisted commercial concessions on agricultural products and only Germany was ready to give generous financial help and the promise of full membership. Turkey, however, would accept nothing less, at least on paper. This new impasse was only overcome after the Cuba crises: Paris accepted to give a sign of solidarity, America's opposition faltered and in spring 1963 the Franco-German "synchronisation agreement" paved the way for a compromise. ${ }^{3}$ The Ankara Treaty signed in September 1963 envisaged a preparatory period of five years that could be lengthened as required. During this period Turkey had no obligations to open her markets and was granted preferential access for four agricultural products (out of the ten it asked for) in exchange of a vague commitment to prepare its economy for integration into the EEC. A Franco-German compromise made provision for $\$ 175$ million of financial aid for five years. And from December 1968, the Association Council could consider whether Turkey's economic state made it possible to move on to the second, 'transitional' phase designed to lead to a customs union and eventual full membership.

3. See relevant documents in RG 59, Bureau of European Affairs OECD, EC and Atlantic PoliticalEconomic Affairs (EUR/RPE) Records relating to European Integration 1962-1966, Lot File 67D33, 5303 box 10, NARA. As for the "rather sudden change of attitude", it resulted "from a combination of factors. First, we tend to agree with the Six that for political reasons the Turkish desire for some tie with the EEC should be satisfied. The Turks have an increasingly uncomfortable feeling of isolation, which was emphasized by the special way in which they became involved in the Cuban crisis. Second, the Turkish government has apparently gone way out on a limb at home in promising association, and its domestic stabilization program could be seriously hurt if association were refused. Third, our special bilateral arrangements with Turkey could also be hurt if, as appeared possible if we stuck to our previous position, the Turks ended up with the feeling that we were the one responsible for a refusal. Last, if an EEC-Turkey arrangement is inevitable, a more positive attitude on our part during the negotiating period will give us a better chance to see that the arrangement does a minimum of harm to our interests, both commercial and political”. See: Joel W. Biller (RPE) to C. Hoyt Price (US mission Bruxelles), 21.12.1962 Confidential, Official-Informal. The Turkish Desk has long supported Turkish reasons. 
The modest commercial provisions of the Ankara agreement depended on the Six as well as on Turkey, and each blamed the other. The 'Second Republic' had espoused an import substitution strategy and protectionism for infant industries and maintained Ottoman mistrust toward foreign capitals and resentment of foreign control. The contradiction between this inward-looking attitude and mutual liberalisation was evident, but import substitution was popular at the time and Turkish products were not considered competitive enough to fuel an export-led development strategy. The lukewarm commitment of the Six was evident, as the meagre commercial concessions were aimed at maintaining existent flows, but did not promote an increase and diversification in exports, mainly owing to Italian footdragging. Financial aid and institutional bonds were the key elements of the relationship, but the Six did not give Turkey a say in future agreements with third countries, as it had with Greece. The choice of association was, then, political: the Turks wanted to be a part of the EEC and the Six were sensitive to this and feared the resentment a refusal would create. They had also seen how volatile Turkish commitments were to healthy finance: in the 1950s the Democrats had been major beneficiaries of US and Western European aid, but they had ignored all allied reproaches about profligacy. In Western circles many hoped that multilateral aid administered by technical agencies would be less exposed to political considerations and blackmail.

The agreement entered into force in 1964, when the Cyprus crisis was going through one of its peaks. ${ }^{4}$ Archbishop Makarios's attempt to alter the 1960 Constitution prompted violence, and a Turkish invasion of the island was probably only averted when president Lyndon Johnson warned Ismet Inönü that Turkey could not count on NATO's help if its initiative provoked Soviet intervention. The "Johnson letter" of June 1964 and the feeling that Turkey had been treated as a bargaining chip in the Cuba crisis led the Turks to reappraise their foreign policy doctrine, the aim being to end the exclusive bond with the West and re-evaluate relations with the Arabs, the Islamic countries, the Eastern bloc and the nonaligned countries. Europe's position in this reappraisal was ambiguous: the article explaining how Turkey would redirect its foreign policy in closer adherence to its national interests admitted that

"due to its social structure Turkey cannot be regarded as a Western country in the real sense of the term [...] Turkey was admitted into the European community because of its geopolitical and strategic situation. It is the only Muslim member of that community. In the past, it was affiliated with another culture. [...] its position in the European community cannot be regarded as strong". ${ }^{5}$

4. B. O'MAlley, I. CRAIG, The Cyprus Conspiracy. America, Espionage and the Turkish Invasion, I.B. Tauris, London/New York, 1999.

5. H. BATU, Turkey's Foreign Policy, in: T.C.Dışişleri Bakanlığı Belleteni, n.6, quoted in: M.B. AYKAN, Turkey's Role in the Organisation of the Islamic Conference: 1960-1992. The Nature of Deviation from the Kemalist Heritage, Vantage Press, New York, 1994, p.61. 
To some extent the Europeans were regarded as sharing the US sin of not supporting Turkey in its willingness and obligation to protect the Turkish Cypriots, but they were also a possible alternative to an exclusive tie with the United States.

The policy of "diversification" won Turkey no real friends in the Cyprus question and the American bond remained crucial. However, chauvinism was encouraged and anti-Western feelings took root across the political spectrum, from the left to the nationalists and the new Islamists. Official pro-Western ideology was not really shaken, but ultra-nationalist leader Alparslan Türkeş and Islamist leader Necmettin Erbakan broadened their support base, and became necessary partners for coalition governments.

\section{Moving towards association}

Despite the bleak outlook, the deteriorating political situation found little space in EEC papers. In October 1967, one year before the deadline set in the Ankara Treaty, the Turks requested the immediate start of preparatory work in view of the end of the first stage. In the Rapport préliminaire sent to the Council in April 1968, the Commission concluded that, although the economic conditions suggested a need to lengthen the preparatory phase, for political and psychological reasons it was better to move to the second stage of the association, as postponement might encourage further delays in economic reforms. ${ }^{6}$ Once again, the economy and politics diverged, with the latter prevailing, although it was not really spelt out what this meant in concrete terms. Turkey probably benefited from remaining a faithful, democratic member of NATO at a time when Greece was under a military junta, France was no longer part of NATO, and Makarios was gambling between the East, West, and non-aligned countries, and harassing the Turkish Cypriots.

The November 1970 Supplementary Protocol, which would only enter into force in January 1973 owing to a long ratification process, confirmed that the EEC and Turkey were heading towards customs union. It was an accord cadre, defining the rules for the dismantlement of mutual barriers in a period between 12 and 22 years. Article 36 stated that free movement of workers would be implemented progressively between 1976 and 1986 and article 39 committed the Six to take measures to extend to Turkish workers social rights enjoyed by EEC workers. As will become clear, both provisions would become bones of contention after 1973. A financial protocol established that Turkey could accede through the EBI to 195 million units of account of financial aid that would be made available by member

6. Historical Archives of the European Union (hereafter HAEU), Fond Edoardo Martino, EM-000092, SEC(68)1386 final, Rapport préliminaire de la Commission au Conseil au sujet du passage de la phase préparatoire à la phase transitoire de l'accord d'association avec la Turquie, 29.04.1968. 
states. ${ }^{7}$ Serious doubts existed about Turkey's ability to withstand the opening of its frontiers, and opposition in Turkey had been strong, from private industrialists, the SPO, and nationalists. However, the international environment was cooperative: while in 1965 the US and UK had criticised the Ankara Treaty in GATT and no agreement had been reached regarding its compatibility with article 24, in 1972 the US delegate only presented five remarks for the record and the Commonwealth and other European countries did not object either. ${ }^{8}$

With the new decade, however, the Turkish political situation had entered a difficult phase, while the economy bore the full brunt of international recession. With the March 1971 "coup by memorandum" the military did not assume direct power, but imposed technical governments of their choice, urging the repression of leftist intellectuals and political and trade union activists, and a restructuring of the party system. Only in October 1973 did elections mark the restoration of democracy. This long emergency regime came as the EEC was making crucial progress and as détente flourished in Europe. "Enlargement" brought three new members and associated status for the other EFTA members. "Deepening" led to new monetary and foreign policy initiatives, and EEC policies toward the Mediterranean, the developing countries, and the Arabs made Turkey's "special relationship" appear modest and obsolete, while the rocky international economy upset the balance of the 1970 Protocol. The December 1973 Copenhagen Declaration maybe did not answer but certainly posed the question of a "European Identity”.

\section{Catching up with "widening and deepening"}

In spite of the political power vacuum, Turkey reacted by attempting to strengthen its ties with the Community and by taking part in Political Cooperation. Three new adhesions to the Community made it necessary to negotiate new commercial agreements with all the Mediterranean countries. ${ }^{9}$ In January 1972 negotiations began, to adapt the Supplementary Protocol to enlargement. Ankara saw this as an opportunity to curtail the obligations agreed upon in 1970, regarded as being too onerous, especially in the deteriorating economic situation; in April a

7. Belgium and the Netherlands, 14,3 million c.u.; Germany and France 65,2 million c.u.; Italy 37,7 million c.u.; Luxembourg, 0,3 million c.u. The EBI itself refused to make her resources available to Turkey. In 1969 the EBI had assumed the management of the consortium for the building of the Bosphorus Bridge, financed by Britain, Germany, Italy and France and built by an Anglo-German firm, with Italian subcontractors. In ten years, the EEC would concede soft loans for 400 Million \$ to Turkey, 300 were spent in infrastructures, 100 in industrial investments.

8. UKNA, FCO 30/1310, Tel. Geneva to FCO, Gatt. Working Party on EEC-Turkey Association Agreement, 11.09.1972, n.117. On US policy see: Foreign Relations of the United States 1969-1976, vol.XXX.

9. HAEU, Fond Franco Maria Malfatti 12, P-48, Le relazioni tra la Comunità e i paesi del bacino mediterraneo, October 1972. 
memorandum pressed for a radical reappraisal of Turkish obligations, including a clause that would permit Turkey to impose import restrictions without consultation in the most important industrial sectors for the next ten years. President in charge Gaston Thorn and the Commission's secretary Emile Noël reacted strongly, expressing doubts about Turkish interest to keep the association going. A difficult period of negotiations followed, until the solemn signing of a Complementary Protocol in June 1973. There were problems regarding the export of cotton textiles to Ireland and Britain and the quantification of British financial aid; the Commission asked for the same amount paid out by France and Germany, but Britain refused, lest a precedent be set for "Yaoundé III"10 or the Mediterranean countries, and proposed to contribute on the basis of its share of the Community's GNP. Once again, then, the fear of a "precedent" proved detrimental to Turkey. In the end, the enlargement brought Turkey an increase in financial aid of $\$ 47$ million.

While the Nine pressed for tough conditions, in Britain both the Foreign Office and the ministry for Trade shared concerns for the future: in the enlarged Community, it appeared impossible that Turkish industry would develop quickly enough to withstand European competition within the timescale envisaged by the association agreements. Therefore, Turkey's admission into the EEC appeared "almost inconceivable in the foreseeable future"; at the same time 'Turkey's association agreement with the EEC [made] little economic sense if full membership of the Community ceases to be the ultimate objective at the end of the provisional period". ${ }^{11}$

"In short, the trade provisions of the association agreement are inappropriate for an economy as backward as that of Turkey. It is arguable that Turkey's economic development would be better served by full participation as a beneficiary in an improved Generalised Preferences Scheme. In these circumstances Association with the Community could still continue of course, but with fewer direct commercial obligations and with other objectives to the fore. The encouragement of Turkey's economic development through aid, technical cooperation and the free movement of workers is already an important objective of the Association; but the extent to which this aspect can be developed depends upon the Community's overall priorities in the aid field. Equally the political motives for Association - the strategic position of Turkey on the shores of the Mediterranean and the Black Sea - has its limitations. The Association Council has not been used in any significant way to increase the political co-operation - as its task has been mainly confined to trade matters, and it appears more of an instrument for keeping Turkey at arm's length than for bringing her into the political counsels of the Community". ${ }^{12}$

This fresh perspective on EEC-Turkish relations pointed out the contradictory nature of a relationship that used economic means to political ends, but whose political foundations were sterile and whose political aims remained unfulfilled,

10. UKNA, FCO 30/2664, Cullimore to Hall, 03.02.1972, confidential.

11. UKNA, FCO 30/2684, Department of Trade and Industry to Cabinet Office, 07.06.1972, The outlook for Turkey.

12. Ibid. 
while the economic stranglehold became tighter and tighter. The British therefore began to sponsor an enhanced approach to Turkey, the aim being to try to improve EEC-Turkish political cooperation and to reshuffle the goals and means of the association so they were more coherent.

Indeed, efforts to secure a place in the EPC had become a leitmotif of Turkish diplomatic action in EEC capitals. As the British recollected, "throughout 1972, the Turkish government pressed hard for closer involvement - ideally some institutional link or even actual participation - in the political consultations". In May 1972 the Six had given a first response: the presidency would give Turkey information about the political deliberations which were of particular interest to her through the political director. In June, Ankara asked to be given information at a ministerial level, in the margin of the Association Council and in the presence of all Foreign ministries. ${ }^{13}$ Then in September the Turks circulated a paper setting out suggestions for closer cooperation, and submitted papers on political subjects. They proposed:

- that the agenda of the forthcoming meeting of the Political Committee should be given to them and they would submit Turkish papers on the subject to be discussed by the Committee;

- that the president of the Council of ministers should have an exchange of views and information with the Turkish minister of Foreign affairs when Council of Association meetings were held;

- that from 1973 the Turkish political director should take part as an observer at the deliberations of the Political Committee. ${ }^{14}$

The Nine took up the second of these proposals ("the first suggestion effectively gives the Turks full knowledge of the scope of the political consultation and indeed an indirect voice in the discussions. The third suggestion actually puts the Turks at the table"):

"It was clear that some gesture had to be made towards Turkey if she was not to be seriously offended but at the same time the Turks were only one of several third countries with close geographical and some sort of treaty relationship with the Community; there was a risk of opening a Pandora's box by accepting either suggestion. The political directors were agreed that full political consultations were for full members only".

The British government acknowledged the need to improve the political dimension of EEC-Turkish relations, to strengthen bilateral relations, and to keep Turkey aligned with pro-Western positions. The Foreign Office was convinced that the economic nonsense of the association regime was only worthwhile if it was balanced by fulfilment of the political aims that were behind it. It also foresaw that

13. HAEU, Fond Emile Noël EN-000655, S/72.25.704, Note [d'Emile Noël] à l'attention de Monsieur Sigrist, Association de la Turquie aux travaux des Dix sur la coopération politique, 28.06.1972.

14. UKNA, FCO 9/1840, G.S. Wright, EEC Political Cooperation: Turkey, 26.01.1973. 
Turkey was bound to be left behind as the EEC moved forward in political and defence cooperation and feared that Washington's declining commitment to European security would leave Turkey isolated. Pro-Western Turks warned that opposition to the EEC and to pro-Western policies was mounting, claimed that the EEC ought to acknowledge that Turkey's economic underdevelopment did not hamper its political maturity, and that they needed to demonstrate to their people that Turkey was accepted as an equal member of the EEC. The defence of Europe, they argued, would be threatened by an un-cooperative Turkey, so an effort should be made to lock Turkey into European cooperation. ${ }^{15}$

\section{In November 1972 the EEC ministerial meeting agreed that}

"the current president $[\ldots]$ should inform the Turkish minister of Foreign affairs on a personal basis of the political consultations in the margin of the meetings of the Council of Association [...]. This decision would not affect the procedure for passing information followed by the president of the Political Committee".

In the meantime, the Nine had ignored Turkey's request to participate in the October Paris summit. As Britain had been shut out of the political consultations until its accession to the EEC had become more than certain and the United States would only obtain a consultation procedure in 1974, Turkey's being the only nonmember country with a formal arrangement for regular information about EPC consultations was not a bad result. However, Ankara continued to press for involvement in the implementation of "common policies". In January 1973, at the CSCE meeting, some Turkish diplomatic noises were interpreted in Western capitals as a signal of problems to come if Turkey was not informed of European strategy and aims. Notwithstanding this, the Nine turned down demands for participation in their consultations. Turkey based its case on its "special position" in EEC external relations, but the Nine feared the "precedent". Furthermore, its argument for claiming participation - to represent the Mediterranean countries excluded from CSCE negotiations - was counterproductive, as the great majority of European governments did not want to discuss Mediterranean issues in the CSCE. A second occasion came in 1974, as European-Arab dialogue got under way. The political director of the Turkish Foreign ministry asked for Turkey to participate in meetings between representatives of the Nine and of the oilproducing countries, and on several occasions Prime minister Bülent Ecevit renewed Turkey's offer to act as a bridge between European and Middle Eastern countries, and put forward plans for cooperation (e.g. concerning Turkish labour and water supplies). ${ }^{16}$

The Nine's reaction was embarrassed and tainted with the usual preoccupation about the psychological impact of rejection and the possible damage to bilateral relations: "If our answer is to be, as I imagine, unenthusiastic, I hope that we can

15. See for example UKNA, FCO 30/1311, R. Sarell (Ankara) to A. Douglas-Home, 28.11.1972.

16. HAEU, EN-001641, Directeur général [Dg.] des Relations extérieures, Note à l'attention de M. Noël. Voyage du président Ortoli en Turquie, 24.04.1974. 
hide behind the French", ${ }^{17}$ commented G.S. Wright of the Foreign Office concerning the Euro-Arab dialogue. The French willingly played the vilains. It was not a new role for them: during the 1962-63 negotiations Turkish support for the Algerian FLN and the limited significance of bilateral trade had prompted France to make things difficult for a renowned US client. Italy, which was Turkey's second commercial partner, had profited from French stubbornness. After 1972, while the French remained aloof - and the Turks suspected Emile Noël of sharing this attitude - and Germany was losing enthusiasm, Britain became Turkey's best friend in the Community. Germany, Italy, and Britain were all keen to retain Turkish goodwill for political and/or commercial reasons, but Britain was in the most favourable position, being able to shelter behind other countries whose worries about specific problems were stronger than its own. For instance, although Britain was concerned about the prospect of the free movement of Turkish workers, Germany was so alarmed that it was prepared to offend Ankara. Moreover, Britain did not want EEC customs to become wide open to Turkish agricultural products, and could count on Italy digging in its heels on concessions. As regards political cooperation, France could be expected to set tight limits and leave Britain to play the nice guy. ${ }^{18}$

Turkish requests were repeated in the EEC-Turkish Joint Parliamentarian Committee. The Nine did seriously discuss it, in the context of the general question about information to third countries, and in the light of the agreed procedure to inform Mediterranean countries with whom the Community was signing association agreements. It was agreed that there could be consultation with allied or friendly countries on an ad hoc, case-by-case basis, and each of the Nine remained free to consult bilaterally, but Ankara did not obtain a special arrangement. Clearly what mattered to Ankara was not so much actual consultations and/or information - after all, NATO and bilateral relations gave plenty of opportunities for that - as it was the formal acknowledgement of its belonging to the core of Europe. Its ambition was both justified and difficult to attain. As the British also admitted,

"the institutionalisation of the political cooperation machinery had not progressed very far and we do not wish to dilute it by formalising links with third parties, however worthy". 19

\section{The Cyprus crisis}

The Foreign ministers of the Nine and the commissioner for External relations Christopher Soames had travelled to Ankara at the end of June 1973 to sign the

17. UKNA, FCO 30/2172, Ankara embassy to G.S. Wright, 11.06.1974, confidential.

18. See for ex. in UKNA, FCO 30/1312, the visit of L. Amery to Ankara in June 1973 and his meeting with Foreign minister Bayülken.

19. UKNA, FCO 30/2172, A.C. Goodison to H. Phillips (Ankara), 28.06.1974. 
Complementary Protocol..$^{20}$ Negotiations for opening a Bureau of Information of the Commission in Ankara were under way. ${ }^{21}$ However, new problems appeared on the horizon when Ecevit stated in the government program of January 1974 that "the protocols to the Association will be revised". This caused reflection in the Commission, where papers trying to explain this lack of mutual enthusiasm circulated. The nature of the agreement was acknowledged to be part of the problem:

"The EEC may feel that it is the wrong kind of agreement at least with a country so different from the Community members as Turkey. And the Turkish attitude to the question of becoming European is ambiguous". ${ }^{22}$

Bilateral problems therefore began to be conceptualized in terms of identity. ${ }^{23}$ The difficulties seemed to stem from the "development provisions" - consultations for co-ordination of economic and commercial policies, and provisions for gradual free access of Turkish workers:

"We do not want to see our freedom of action in trade policy limited by having to take into account the interests of others; we certainly do not like to let anybody have a say in our formulation and carrying out of policies; and Turkey is not the first country of our choice today to whom such a particular role would be given".

Turkey's record on the ten years of association was negative:

"Turkey has not changed fundamentally since the present agreement was concluded. Except for isolated areas of industrialization, Turkey is basically much the same, politically and economically as 10 years ago".

However, demoralising remarks about the past, the present, and the future of the relationship did not lead to any concrete proposals as to how to revive or revise the relationship. "I frankly do not know, and remain convinced [...] that Turkey will remain a not at all easy partner, whatever we do, for a good many years to come", admitted Inge Nielsen from the External relations directorate. A paper prepared prior to president François Xavier Ortoli's visit to Turkey in April 1974 to answer the question "si l'association a atteint son but économique principal, c'est-à-dire si elle a contribué à aider la Turquie à sortir de son sous-développement" 24 also stressed the lukewarm attitude of both parties.

Ecevit did not ask Ortoli for any revision, but complained heavily about Turkey being "left aside" by the EPC and about delays in the implementation of the social provisions for Turkish workers agreed in the Supplementary Protocol. ${ }^{25}$ In August

20. It would enter into force only in 1986, but an accord intérimaire made the commercial provisions effective as of 01.01.1974.

21. HAEU, EN-1995, Aide-mémoire. Création d'un bureau de presse et d'information de la Commission des Communautés européennes en Turquie, 19.06.1973.

22. HAEU, EN-1641, Inge Nielsen, Some thoughts on the EEC-Turkey Association, 09.04.1974.

23. See also UKNA FCO 30/1311, R. Sarell (Ankara) to A. Douglas-Home, 28.11.1972.

24. Note à l'attention de M.Noël, 24.04.1974, op.cit.

25. HAEU, EN-001103, Entretien avec M.Ecevit. 
he secretly ordered the SPO and the ministry of Commerce to prepare a review of EEC-Turkish relations.

After 1973, major problems and contrasts did indeed come from articles 36 and 39 (concerning the free movement of workers and social rights) of the Supplementary Protocol. During the 1960s, remittances from Turkish workers in the EEC had risen to 1 billion dollars, covering one third of the balance of payments deficit. But after the oil shock, article 36 became a nightmare for Germany, which, at the end of 1973, imposed a ban on recruitment of guest workers. Studies estimated there might be as many as 10 million Turkish workers in Germany by 1990 if free movement was implemented and in the summer of 1974 Bonn considered how to face the problem, suggesting, in a memorandum, "assisted free movement", i.e. a system of controls. ${ }^{26}$ Britain and Germany more or less agreed to make common cause in holding up implementation of free movement by failing to reach unanimity on the regulations in the Council of Association, only disagreeing on who would take the lead. ${ }^{27}$ As for article 39, discussions in the Association bodies run into serious difficulties, as the Europeans baulked at the prospect of having to pay high social welfare benefits for Turkish workers. Problems also arose in the agricultural negotiations. The Global Mediterranean Policy eroded Turkish privileges, Spain and Israel in particular had obtained important concessions, and Commission members grew impatient at Turkish complaints and requests. On the other hand, the Europeans condemned Turkish legislation against foreign investments and in general discrimination and hostile rules that penalised foreign economic activities in Turkey; this would be insistently criticised as neo-liberal positions developed towards the end of the decade. ${ }^{28}$

However, Turkish worries in the summer of 1974 were nothing compared to its fears and disappointment following the Cyprus invasion, the fall of the colonels, and the Greek announcement of its intention to apply for full membership as soon as possible. The principle of parallelism was once again vigorously argued by Ankara in EEC circles:

"[La Turquie] ne pouvait concevoir une adhésion de la Grèce à la Communauté sans adhésion de la Turquie, sinon simultanée du moins proche. Cette politique de parité dans les rapports avec l'Europe avait toujours été celle du Gouvernement turc et avait été reconnue du coté de la Communauté, comme en témoignent les similitudes des traités d'association de la Communauté avec la Grèce et avec la Turquie". ${ }^{29}$

26. UKNA, FCO 30/2172, B.L. Crowe (Bonn) to R.Q. Braithwaite (EID), 19.07.1974.

27. Ibid.

28. See for ex. the report on a seminar on the EEC-Turkey relations, held in Antalya in October 1976: HAEU, EN-000826. In general on the period, see Documents on British Policy Overseas, series III, vol.V, The Southern Flank in Crisis, 1973-1976, Routledge, London, 2006.

29. HAEU, EN-001104, P.689/74, E. Noël, Note à l'attention de M. Ortoli, Entretien avec l'ambassadeur Saraçoglu, 10.09.1974. 
European reactions to the Cyprus imbroglio were embarrassed and unimpressive. Initial understanding of Turkey's motives gave way to condemnation as Turkish forces held more than one third of the island and thousands of Greek Cypriots were displaced and harassed. The EPC as such kept a low profile and also the UK excluded that economic carrots could be given to Turkey to encourage it to withdraw its forces. The question was almost absent in the Association Council held in September 1974. The situation worsened as Turkey fell into political chaos: in spite of the huge popularity the Cyprus invasion gave the Prime minister, Ecevit's government did not survive and his resignation opened a long crisis. An above-party cabinet stayed on until, at the end of March 1975, Süleyman Demirel formed the so-called Nationalist Front, with Necmettin Erbakan and Alparslan Turkeş as the main partners. In the meantime, the Turkish-Cypriot leader Rauf Denktaş, with the backing of the Turkish nationalists and military, took measures to consolidate partition in Cyprus, thereby driving Turkey up a blind alley: at best, the Turkish leadership was suspected of not doing enough to stop Denktaş and to push him to compromise, at worst to be behind the move. On 5 February 1975 the US Senate, in an act of defiance towards Henry Kissinger, had imposed a ban on arms supplies to Turkey. Kissinger was unable to obtain withdrawal of the ban, and the crisis rumbled on for months, involving NATO - after the French and Greek withdrawal it was not inconceivable that Turkey might follow them - and placing the Europeans in a dilemma when Turkey asked for political solidarity and military supplies. ${ }^{30}$

Fears about a Turkish withdrawal from the alliance were soon allayed: the Turkish government declared it to be "out of the question" and only reduced cooperation on American military and intelligence installations, and abstained from participating in NATO's September exercises in the Mediterranean. However, Ankara took the question of the arms embargo to NATO and asked the European members of the alliance to make up the shortfall in supplies resulting from the American ban. Generally speaking, the Europeans considered the US ban to be a major error, in so far that it radicalised both the Turks and the Greeks and made compromise more difficult. On 13 February the EPC issued a good-will declaration, but with no conspicuous result. On the other hand, by cultivating in a more or less coordinated way each of its bilateral relations with the parties in the crisis, the Nine managed to maintain a balanced approach. France's penchant for Greece was confirmed and its return to democracy obviously favoured Athens. Later, however, Greece's withdrawal from the military organisation of NATO put Turkey in a positive light as the Eastern pillar of the alliance. The British cabinet decided to consider the Turkish arms shopping list sympathetically and to allow the sale, on commercial terms (aid was excluded), of such military equipment as was relevant to Turkey's ability to discharge her obligations towards NATO defence, warning that the situation would be reviewed if new fighting involved Turkish troops in Cyprus. London also approached members of the US Senate to try to

30. B. O'MALLEY, I. CRAIG, op.cit., pp.225-227. 
speed up the end of the ban. Britain remained committed to keep the relationship going. But economic bilateral issues soured the atmosphere. A mini-trade war had erupted over cotton yarn, when the British introduced import licensing at the end of 1974 after Turkish exports had increased almost tenfold in the previous two years, cotton products being the only commodity to benefit enormously, and unexpectedly, from the association provisions. The Turks had retaliated by restricting imports of polyethylene, synthetic rubber, excavating machinery, and forklift trucks. The British passed the question to the Commission and this defused the bilateral tension, but virtually put Turkey into a corner. When in June the Turks became incensed by the participation of Makarios at the EEC-Cyprus Association Council meeting, London suggested that Denktaş ask for a meeting with the Commission, but it did not accept the Turkish request for it to oppose the Makarios meeting.

For its own part, in March 1975 the FRG resumed arms sales to both Turkey and Greece, ${ }^{31}$ and in June Foreign minister Hans Dietrich Genscher travelled to Turkey. Bonn was to the fore in trying to defuse the Turkish-American crisis over arms supplies and American use of Turkish military facilities.32 In 1976 the minister for Armaments, Georg Leber, and chancellor Helmut Schmidt also visited Ankara in an effort to keep political relations on a normal footing. ${ }^{33}$

\section{A fragmented outlook}

However, time worked against Turkey in the Cyprus crisis. Its position steadily deteriorated into resentful isolation and during 1975 EEC-Turkish relations grew more and more tense. Within the Commission, a lively debate took place in springsummer 1975. The Turkish Desk of the Foreign relations directorate, Caporale, was among those growing impatient, describing the Turks as "unorthodox and utterly frustrating", unable to discuss "in a civilized manner" questions such as the EEC's Mediterranean Policy or free movement. ${ }^{34}$ Not everybody was so negative: in April 1975, commissioner Carlo Scarascia Mugnozza visited Turkey and reported the alarmed views of Western diplomats and EEC functionaries, urged the Commission to look seriously at the whole state of EEC-Turkish relations and to work on breaking an impasse that was not only Turkey's fault. Scarascia wrote an impassioned plaidoyer for a relaunching of the association: the domestic situation was so unpredictable, the pro-Western circles so weak and besieged, the regional environment so unstable, and Turkey's international ties so relaxed that anything

31. Akten zur Auswärtigen Politik der Bundesrepublik Deutschland (hereafter AAP) 1975, docs.32 and 57.

32. See the Genscher-Demirel conversations in AAP 1975, doc.170.

33. AAP 1976, doc.30 and pp.724-736.

34. UKNA, FCO 30/2684, R. James, Meeting with M. Caporale, Friday 20th June, 23.06.1975; ECO $6 / 32$, restricted. 
could happen. Moreover, Scarascia, like many others, took it almost for granted that Turkey would follow suit in the event of a Greek application for full membership, and to prevent this "nightmarish" prospect the EEC ought to move in advance and propose "un fonctionnement plus politique des institutions de l'association, avec des formes de consultation et de rapports beaucoup plus significatives". 35

In fact, as Greece's application materialised, Turkey launched an effort to catch up. To everybody's relief, Turkey's own application was only mentioned as a remote threat, but Ankara claimed that the Greek application - made for "purely political reasons" and with the goal of "driving Turkey back into Asia" - had to be counter-balanced by giving Turkey an enhanced political association. In May 1975 a memorandum was sent to the Italian presidency in advance of the Association Council to be held on 16 September. At the meeting, president Mariano Rumor had the uncomfortable task of making it clear that the Nine would not modify the agreed procedure. ${ }^{36}$ In the weeks before the meeting, the British had actively worked for this result, sponsoring the line of gentle firmness, ${ }^{37}$ and in the aftermath of the meeting, when Germany suggested discussing the question again, stuck to the need to "uphold the firm statement on political cooperation made to the Turks at the Association Council by Rumor". The Turks were not to use the Political Cooperation machinery to offset eventual Greek membership.

In July the German government had also launched a wide-ranging diplomatic action to collect support for a restrictive approach to the question of the free movement of workers. Although the initiative was not aimed exclusively at Turkey, but also at other Mediterranean countries with which agreements were negotiated, Turkey was obviously affected. The Germans argued that the Community position had developed against a background of an over-optimistic assumption about the absorptive power of Community labour markets; the current difficulties were not temporary and this ought to be taken into account in negotiations. Articles 36 and 39 of the Association Agreement were a huge problem and the Germans were determined to prevent free movement becoming effective. ${ }^{38}$

In the Commission something was moving however. Although Scarascia's almost emotional proposals apparently did not strike the right chords in Brussels, as Soames' response was lukewarm, in December 1975, Giampaolo Papa, the Commission's representative in Ankara, came out with the proposal for a "global approach" to Turkey. This involved setting certain deadlines in the next ten years for agricultural concessions and in other fields, in order to produce a political and

35. HAEU, Fond Carlo Scarascia Mugnozza CSM 49, C.Scarascia Mugnozza to C.Soames, 10.04.1975.

36. UKNA, FCO 9/2349, Note of meeting between the president of the Council and the Turkish Foreign minister in the Political Cooperation Framework, $16^{\text {th }}$ September.

37. UKNA, FCO 9/2349, EEC Council of ministers, 15-16.09.1975, Brief VII: $21^{\text {st }}$ meeting of the EECTurkey Association Council.

38. UKNA, FCO 30/2684, Rimington to Moore, 09.07.1975. Talks with Herr Arendt. 
psychological effect capable of relaunching the dialogue. The "global approach" probably had other objectives as well: to resist the Turkish demand for the mostfavoured nation clause in agricultural products and to overcome the quarrels that paralysed the Nine every time measures were discussed that affected only one sector. The "global approach" was not adopted but it was agreed that the relationship needed to be restored.

How problematic this was in the difficult conditions of the late 1970s would become clear during the long months in which an internal compromise was sought. In February 1976, the preparation of the next association council was already in a situation of total impasse on agricultural issues, as the member states opposed the Commission's proposal to extend to Turkey the better conditions enjoyed by other Mediterranean countries for all products. Only products that were really important for the Turkish economy should have privileged status, they argued. "L'association", stated Jean-Marie Soutou on behalf of France, "n'est pas un accord commercial et [...] il est donc pas question d'y introduire la clause de la nation la plus favorisée". ${ }^{39}$ Thorn invited the Foreign ministers to a debate on the future of the Association on the political, economic, financial, and social plans. The Mediterranean Policy, which offered all the countries situated on the shores of the Mediterranean commercial privileges and financial aid, was a real setback for Turkey. Psychologically, it ended the "special relationship" with the EEC, while in practical terms it produced an erosion of Turkish privileges. In particular, the 1975 free trade agreement with Israel was received with dismay in Turkey. Moreover, some member states had "clients" among the new partners in whom they were much more interested than in Turkey. In 1976, it was plain in EEC circles that the 1973 Complementary Protocol had been rendered obsolete by recent and dramatic economic changes.

Although everybody accepted that association had very little benefit for Turkey, owing to the "internationalisation of the economy", the Mediterranean Policy etc., the paucity of what member states were ready to concede and their incapacity to agree what was the "minimum présentable" to Turkey resulted in stalemate. In June, the discussion of the Mediterranean Financial Protocols demonstrated that Turkey had fallen down the list of priorities. Not only was Turkey just one more country in a group that also included Greece, the Mashriq, Israel and Cyprus. France wanted to give Greece more financial aid than Turkey, reversing an established informal rule, and in the end it accepted only a 30 million unit of account surplus for Turkey, instead of the 120 requested by Britain and the Commission. Furthermore, whatever the "péripéties de la réunion avec la Turquie",

39. HAEU, EN-1107, 804e réunion du Comité des représentants permanents: 26.02.1976. Préparation du Conseil d'Association CEE-Turquie. 
France wanted negotiations with Greece to solemnly open on $30 \mathrm{July} .{ }^{40}$ On the other hand, the Commission ruled out any proposal for "actions concrètes dans le domaine tarifaire": "toute action impliquerait que la Communauté propose [...] de revoir l'accord d'association". In view of the negotiations with Greece, this could be interpreted as a "remise en cause" of the final objective of Turkish adhesion.

In mid July 1976, a package of four volets was ready for Turkey, in view of the Association Council to be held on 24 July, three days before the opening of the Greek negotiations. On the questions of the free movement of workers and agrarian exports, Germany, France, and Italy considered they had gone as far as they could. The package actually contained no concessions on migrant workers, as it considered Turks on the same level as other foreigners, and little on agriculture; the third volet, development of the association, offered industrial and technical cooperation, and the fourth contained 310 million units of account of financial aid. Turkey refused the package and postponed the Association Council.

This dramatic step took place in a deteriorating climate. The German government was now in the forefront trying to keep the dialogue going. In May chancellor Schmidt had visited Ankara and held conversations with Süleyman Demirel and Foreign minister Ishan Sabri Caglayangil. In spite of the warm political intimacy and the flow of military and economic aid that Bonn continued to give, ${ }^{41}$ many political and economic difficulties stood in the way. ${ }^{42}$ In its search for support on the Cyprus issue, a few days previously Ankara had hosted the seventh meeting of the Foreign ministries of the Islamic Conference Organisation: a resolution calling for Israel's expulsion from the UN had been adopted and Turkey had declared that it would approve the Charter of the ICO and allow the opening of a PLO office in Ankara. ${ }^{43}$ In June, Demirel received Todor Zivkov, Josip Tito, and Nicolea Ceaucescu. In the meantime, a US-Turkish arms agreement signed in March still awaited US ratification. Economic bones of contention included the stagnation of German and Western investments in Turkey, financial aid, and the opening of EEC markets to Turkish exports. However, the biggest problem by far was that of Turkish workers, over which Germany refused to comply with the EEC's commitment. German inflexibility stemmed directly from Schmidt, but was only in part a fruit of the forthcoming elections. In Schmidt's view, Germany should not allow a problem of minorities to develop, therefore no new Turkish

40. HAEU, EN-00653, Protocols financiers Méditerranée, 21.06.1976; France's closure toward Turkey was evident in the Schmidt-Giscard conversations of early July: while Giscard confirmed that Greece had to be accepted as a member, he also stated: "Frankreich werde nie eine Mitgliedschaft der Türkei, Israels, der Maghreb - oder Mashrek-Staaten akzeptieren”: AAP 1976, doc.227, 13 th July 1976, pp.1051-1054, here: 1052.

41. Until 1976 Germany gave capital aid as of 2986 Million DM, Turkey was second after India; since 1964 Germany gave yearly military aid to Turkey according to a NATO Council decision.

42. See AAP 1976, pp.724-736.

43. Turkey had begun to actively support the PLO and its claim for a Palestinian state in 1974, reversing its previous stand against international terrorism; in 1975 it voted in favour of a UN draft resolution describing Zionism as a form of racism. See M.B. AYKAN, op.cit., pp.76-79. 
Gastarbeiter should settle in Germany. ${ }^{44}$ But Gastarbeiter remittances covered one third of Turkey's balance of payment deficit, and Turkey could not easily forego such an influx. It also did not want to accept a withdrawal of a commitment assumed by the Community years before. As ambassador Gustav Adolf Sonnenhol commented:

"Both sides have for years omitted to talk about this question, hiding their head in the sand: in Ankara, because all they could think about were the workers' remittances as a support for the balance of payments, and us, because we have not been able to agree on a decent foreign workers' policy that is fair for the country of origin on political and development policy grounds".

According to the ambassador, however, it was impossible to isolate the question from the position of Turkey in NATO, the question of Greece's accession to the EEC, and Turkey's relations with the EEC.

"In the two critical years since the beginning of the Cyprus crisis the position of the West in Turkey has been kept in place above all through the Federal Republic. We have remained practically the only credible speaker for European and Atlantic interests. If we fall by the wayside as well, and if the Congress does not authorize the TurkishAmerican military agreements, in the ensuing realignment of Turkish policy, the relationship with Europe could also be questioned. Even without this, the association with the EC has more enemies here than supporters. It would be tragic if the bridge collapsed as a consequence of a domestically motivated, short-sighted attitude of the Federal Republic". 45

But the ambassador also criticised the German government for having tried to hide behind the Community. In his view, Germany should find a solution with Turkey and then get the Community to endorse it.

A new question erupted in August: the Greek-Turkish quarrel about the Aegean continental shelf revived and Turkey found itself under pressure from both the UN Security Council and the EEC, in which the pro-Greek attitude of the president in charge, Dutch Foreign minister Max van der Stoel, was balanced by the External Relations Commissioner Soames, supported by the Germans and the Danes. ${ }^{46}$

After the Association Council was again postponed in October, small concessions on agriculture and financial aid were envisaged; but a compromise had to be found on the free movement of workers. Emile Noël's "second priority" formula - that Turkish workers have priority over other non-Community workers slowly gained ground, and was able to give Turkey a psychological premium while conceding nothing substantial in the current conditions of European unemployment. ${ }^{47}$ The Association Council held on 20 December 1976 sealed a meagre agreement.

44. AAP 1976, doc.241, footnote 6 .

45. AAP 1976, doc.261, Sonnenhol to A.A., 11.08.1976, pp.1194-1219, here: p.1196.

46. AAP 1976, doc.283, Konferenz der Außenminister der EG-Mitgliedstaaten in Beesterzwaag, 12.09.1976.

47. HAEU, EN-000826, E. Noël to J.C. Paye, 22.10.1976, personnel. 


\section{"Like any other third country"}

In 1976 the famous Turkish journalist Mehmet Ali Birand, then the only Turkish journalist accredited at the EEC, reported sadly in Milliyet that, according to a high member of the Commission, Turkey "no longer had a special status and had to be considered like any other third country". Some Commission members had been mumbling this for years, arguing that the reasons behind the 1963 Association Agreement did not exist anymore and that the EEC's political, geographical, and economic priorities had changed. So a country that in 1959 had gone for membership of the European Community seemed, at the end of the 1970s, both unwilling and unable to keep pace with developments in the Community. But the causes went back a long way, and lay in the basic lack of coherence between economic instruments and political aims in the EEC-Turkish relationship. Economic difficulties were allowed to strain the relationship and a gap in the economic approach deepened in the late 1970s, as Europe slowly moved toward neoliberal strategies and clashed with Turkey on its resistance to opening its market to foreign investments. Absorbed by their domestic problems, the EEC countries refused to concede Turkey even minor economic prizes. On the contrary, they hid opportunistically behind the Community and pretended that economic problems could be isolated from political relations.

At the same time the EEC countries did not consider the Community to be a political actor with a role to play in the Eastern Mediterranean. Few felt that the EPC was the right instrument to balance the loosening EEC bonds. The governments placed tight limits on it, and the British and Germans, who at different times took the lead in political dialogue, shared a reluctance to open the doors of the EPC to Ankara. Nationalism and anti-Western feelings in Turkish politics played a big role in strengthening the gap, and the Cyprus issue placed Turkey in a corner. In 1980, Turkey's third and most devastating coup d'état plunged the country back into authoritarianism, political captivity, and human rights violations, while in Western Europe the age of dictators and political violence was becoming a thing of the past. Turkey would take a long time to free itself from this bitter heritage. 


\section{Die Türkei und \\ die Europäische Union}

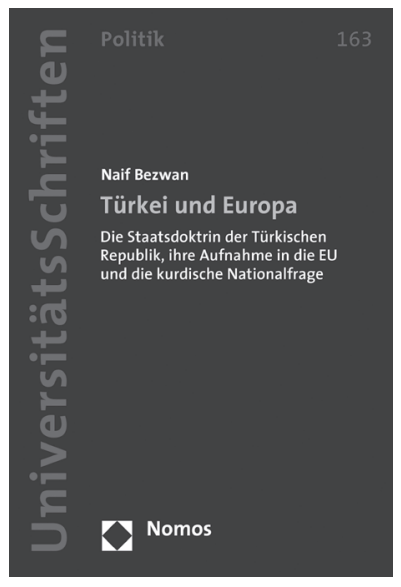

\section{Türkei und Europa}

Die Staatsdoktrin der Türkischen Republik, ihre Aufnahme in die EU und die kurdische Nationalfrage

Von Naif Bezwan

2008, 347 S., brosch., 59,- $€$,

ISBN 978-3-8329-4000-3

(Nomos Universitätsschriften - Politik, Bd. 163)

Der Türkischen Republik liegt eine offizielle Staatsdoktrin zugrunde, die die türkische Vorherrschaft über andere Völker der Türkei fundiert und forciert, dem Militär eine beherrschende Rolle im politischen System zuschreibt und dementsprechend den Beitritt der Türkei zur EU nur unter dem Vorbehalt des Fortbestandes eben dieser Staatsauffassung verfolgt.

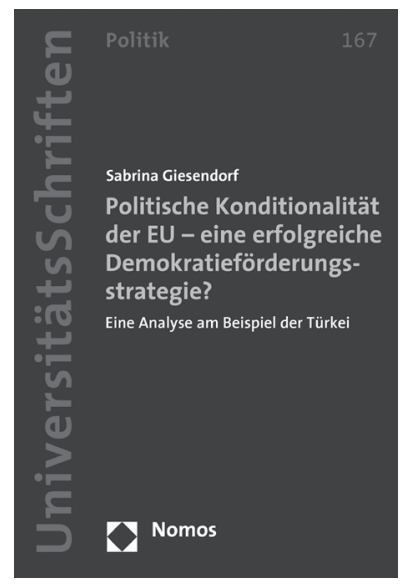

Politische Konditionalität der EU eine erfolgreiche Demokratieförderungsstrategie?

Eine Analyse am Beispiel der Türkei

Von Sabrina Giesendorf

2009, 439 S., brosch., 89,-€,

ISBN 978-3-8329-4535-O

(Nomos Universitätsschriften - Politik, Bd. 167)

EU-Erweiterungspolitik als Strategie der Demokratieförderung? In dieser theoretisch und empirisch fundierten sowie strukturierten Analyse wird der Einfluss der EU auf die Konsolidierung demokratischer Strukturen in der Türkei untersucht. Im Zentrum steht die Frage, inwiefern die EU mit ihrem exklusiven Instrument der politischen Konditionalität Demokratie effektiv fördert. 